\title{
Ecophysiological Responses of Two Olive Tree Cultivars (Olea europaea L. CV Koroneiki and Chemlali) Under Three Water Treatments
}

\author{
Mortadha Ben Hassine, PhD \\ Higher Institute of Agricultural Sciences of Chott Mariem, \\ 4042 Chott Mariem, Sousse, Tunisia and Olive tree Institute, \\ Unit of Sousse, BP n 14 Ibn Khaldoun, 4061 Sousse, Tunisia \\ Olfa Boussadia \\ Amani Bchir \\ Ines Moula \\ Mariem EI Hafi \\ Mohamed Braham
}

Olive Tree Institute, Unit of Sousse, BP n${ }^{\circ} 14$ Ibn Khaldoun, 4061 Sousse, Tunisia

doi: 10.19044/esj.2016.v13n3p327 URL:http://dx.doi.org/10.19044/esj.2016.v13n3p327

\section{Abstract}

In this paper, our objective is to assess and compare the effects of three levels of irrigation application on the ecophysiological behavior and plant dry matter accumulation of two young olive tree cultivars Koroneiki, a promising greek cultivar, and Chemlali, the best local cultivar. According to this assessment, we can determine the most efficient water treatment that could be suitable for Mediterranean environments subjected to water shortage conditions. Measurements were made in the green house of the Tunisian Olive tree Institute under normal day-light conditions from March, $16^{\text {th }}$ to April, $21^{\text {st }}$ 2015. Three water treatments were applied which are T100\% (control treatment: Daily irrigation at 100\% of Available Water Content (AWC)), T50\% (Daily irrigation at 50\% of AWC) and T0\% (Without watering). The results showed that the two olive tree cultivars possess important mechanisms to overtake limited water resources. However, some striking variations existed between the two cultivars studied. Indeed, as water stress increased (T0\%), Chemlali maintained longer a high midday leaf water potential compared (- $4.54 \mathrm{MPa})$ to Koroneiki (- 5.8 $\mathrm{MPa}$ ). T50\% treatment seems to be sufficient for both cultivars. Measurements of total Osmotic Adjustment (OA) showed that olive trees use this mechanism to create very negative leaf water potentials in order to be 
able to extract water from a dry root environment. The root/shoot ratio of Chemlali plants at T50\% treatment was the highest (1.08) comparatively with the other two treatments $(0.70$ and 0.79 for $\mathrm{T} 100 \%$ and T0\% AWC water treatments, respectively). This result shows that Chemlali plants valorize low quantities of water (T50\%) rather than high quantities (T100\%) and Koroneiki plants behave better when it is irrigated at $100 \%$ AWC. To conclude, Chemlali plants irrigated at 50\% AWC, compared to Koroneiki plants, are the most suitable to tolerate water restriction conditions.

Keywords: Olea europaea L., leaf water potential, osmotic adjustment, ecophysiological behavior, plant dry matter accumulation.

\section{Introduction}

Nowadays, $98 \%$ of the worldwide olive trees are cultivated within the Mediterranean area. This region represents, from a climatological point of view, a transitional area between temperate and tropical climates. In semiarid Mediterranean zone, like Tunisia, the climate is characterized by an irregularity precipitations and hot and dry summers. In the long-term, this situation could become more and more exacerbated, considering the increased risk of aridity caused by warming climate. Olive trees grown in these regions are often exposed to a long period of drought and harsh environmental conditions, which affects tree growth and, hence, olive growing development. Much of the land, where olive trees are grown, is intrinsically incapable of producing profitable crops under dry-farming conditions. In Tunisia, in order to increase productivity of olive trees, the intensification of this culture sector is a necessity.

The expansion of irrigated olive farming and the increasing concern for quality of the harvested products lead to the introduction of cultivars from the northern zone of the Mediterranean in Tunisia. Koroneiki is the main olive cultivar grown for oil in Greece. This cultivar can be planted in highdensity orchards, but has also potential for the more traditional non-irrigated production sites.

During the last decade, effort has been put in a sustainable development of the olive orchards in Tunisia applying irrigation and fertilisation in order to improve the productivity and quality of olive oil. Till now, no study about the suitability of Koroneiki cultivar for a more arid climate is available, nor is it known how this cultivar compares with local cultivars under drought and irrigation conditions. Studying physiological responses to irrigation supply may help to get fundamental and new insights into how this cultivar responds to water demand.

Different cultivars respond differently to water treatment showing differences in terms of adaptation, dry matter distribution, production and 
gas exchange responses to water shortage (Chartzoulakis et al.,1999; Bacelar et al., 2004, 2007; Tognetti et al., 2002).

In this context, the main aim of this work was to assess the behavior of two young olive tree cultivars Koroneiki, which is a promising Greek cultivar for oil production, and Chemlali, the best local cultivar for oil production, under three water treatments. The comparison between the two cultivars was based on water status, eco-physiological and dry matter accumulation parameters. This study is essential to select the most suitable cultivar for Mediterranean environments subjected to water shortage conditions.

\section{Material and methods}

\section{Plant material and water treatments}

One-year-old olive trees (Koroneiki and Chemlali) were grown in 4L plastic pots in a greenhouse at the Tunisian Olive tree Institute (Tunisia, 35 $49^{\prime} \mathrm{N}, 1038^{\prime} \mathrm{E}$ ) under normal day-light conditions with an average temperature of $25^{\circ} \mathrm{C}$ and relative humidity of $40 \%$. Prior to the start of the experiment, trees with a height of about $1 \mathrm{~m}$ were selected and lifted from a soil mix of organic material, sand and clay. Roots were washed and plants were transplanted into a substrate mixture of peat and perlite (2/3 volume ratio). A full-strength before starting, the plants were watered daily to $100 \%$ of Available Water Content (AWC) for a period of 4 weeks with a Hoagland solution. Then, plants were divided into two parts: the first one (control plants) was subjected to irrigation to $100 \%$ of AWC and the second one to drying until reaching $50 \%$ of AWC.

The experiment was conducted from March, $16^{\text {th }}$ to April, $21^{\text {st }} 2015$. Three water treatments were applied:

- T100\%: Control treatment: Daily irrigation at 100\% of Available Water Content (AWC),

- T50\%: Daily irrigation at 50\% of AWC,

- T0\%: Without watering.

Control and drought-stressed plants were arranged in a complete randomized design with eight replications for each cultivar. Water treatments (three levels of water application) and cultivars (two) were considered as treatments. In total, 48 olive plants were used (8 plants of each cultivar/water treatment).

\section{Leaf water status measurements}

Plant water status was determined by measuring the total leaf water potential $\left(\Psi_{\mathrm{w}}\right)$ on fully expanded leaves (taken from the mid-section of the shoots). 
Three plants per treatment were measured at midday (12 am) with a thermocouple psychrometer (sample chambers type C52; Wescor, Logan, Utah, USA) following the method described by Chazen et al. (1995). For each plant and at each measurement event, a sample (surface area of the leaf disc $=0.25 \mathrm{~cm}^{2}$ ) was used to measure $\Psi_{\mathrm{w}}$. Osmotic adjustment (OA) was calculated for both cultivars by taking the difference between midday $\Psi \pi$ measured at control (T100\%) and stressed (T50\% and T0\%) plants.

\section{Gas exchange measurements}

Fully expanded leaves were used to measure simultaneously maximum net photosynthetic assimilation rate $\mathrm{A}\left(\mu \mathrm{mol} \mathrm{CO}_{2} \mathrm{~m}^{-2} \mathrm{~s}^{-1}\right)$ and stomatal conductance for water vapour gs (mol $\mathrm{H}_{2} \mathrm{O} \mathrm{m}^{-2} \mathrm{~s}^{-1}$ ) using a portable gas exchange system (LI-6400, LI-COR, Lincoln, NE, USA).

The A/gs ratio was calculated and used as an estimate of the intrinsic water use efficiency (WUE) according to Mediavilla et al. (2002).

Measurements were performed weekly in three replicates for each treatment and cultivar. Measurements of A and gs were performed at light saturation $\left(1500 \mu \mathrm{mol}\right.$ PAR m $\left.\mathrm{m}^{-2} \mathrm{~s}^{-1}\right)$ between $11 \mathrm{am}$ and $2 \mathrm{pm}$ and at a fixed $\mathrm{CO}_{2}$ concentration (Ca equal to $400 \mu \mathrm{mol} \mathrm{mol}^{-1}$ ), with a leaf temperature of $25^{\circ} \mathrm{C}$ and a relative humidity of $50 \%$.

\section{Plant dry matter accumulation}

At the end of the water stress application (April, 21 ${ }^{\text {st }}$ 2015), plants destruction was done in order to determine the dry weight body (leaves, root and stem).

\section{Statistical analysis}

The mean data were statistically analyzed using SPSS 16.0. Significant differences between treatments were determined by one way analysis of variance. Student-Newman-Keuls's multiple range test was used to compare the means.

\section{Results and discussion}

\section{Effect of three water treatments on leaf water status}

Effect of three water treatments on leaf water potential

Figure 1 shows the effect of three water treatments on the leaf water potential $\left(\Psi_{\mathrm{w}}\right)$ of olive tree (Olea europaea L. cv Koroneiki and Chemlali). For both cultivars, T100\% plants show the highest leaf water potential however T0\% plants show the lowest one throughout the experiment period. For Koroneiki plants, after 21 days of applying water treatments, a significant difference was observed between T0\% and the two other 
treatments (T100\% and T50\%). But, no significant difference was noticed between Koroneiki T100\% and T50\% plants during the experiment period.

The leaf water potential of Koroneiki T0\% plants decreases to - 5.8 MPa after 35 days of applying water treatments which represent $59.8 \%$ comparatively with the control plants.

For Chemlali plants, 35 days after applying water treatments, no significant difference was observed between T100\% and T50\%, while, the leaf water potential of T0\% plants decreases to - $4.54 \mathrm{MPa}$, which represent $35.93 \%$ comparatively with $\mathrm{T} 100 \%$ plants. It should be noted that a significant difference between Koroneiki and Chemlali plants was recorded in T0\%. According to these results, we can deduce that Chemlali plants are more tolerant to water restriction than Koroneiki plants.

For both cultivars, Irrigation at 50\% AWC permits to maintain regular leaf water potential. Our results are similar with those obtained by Giron et al. (2015) despite that the experiment was conducted in field conditions and showed lower values mainly in the middle of the water stress period (from DOY 207 until 220), though values on the stress treatment tended to be lower throughout the water stress period.

According to Marino et al. (2014), under severe drought, the leaf water potential ranged between $\sim-4.5 \mathrm{MPa}$ (predawn) and -6.4 MPa (midday).

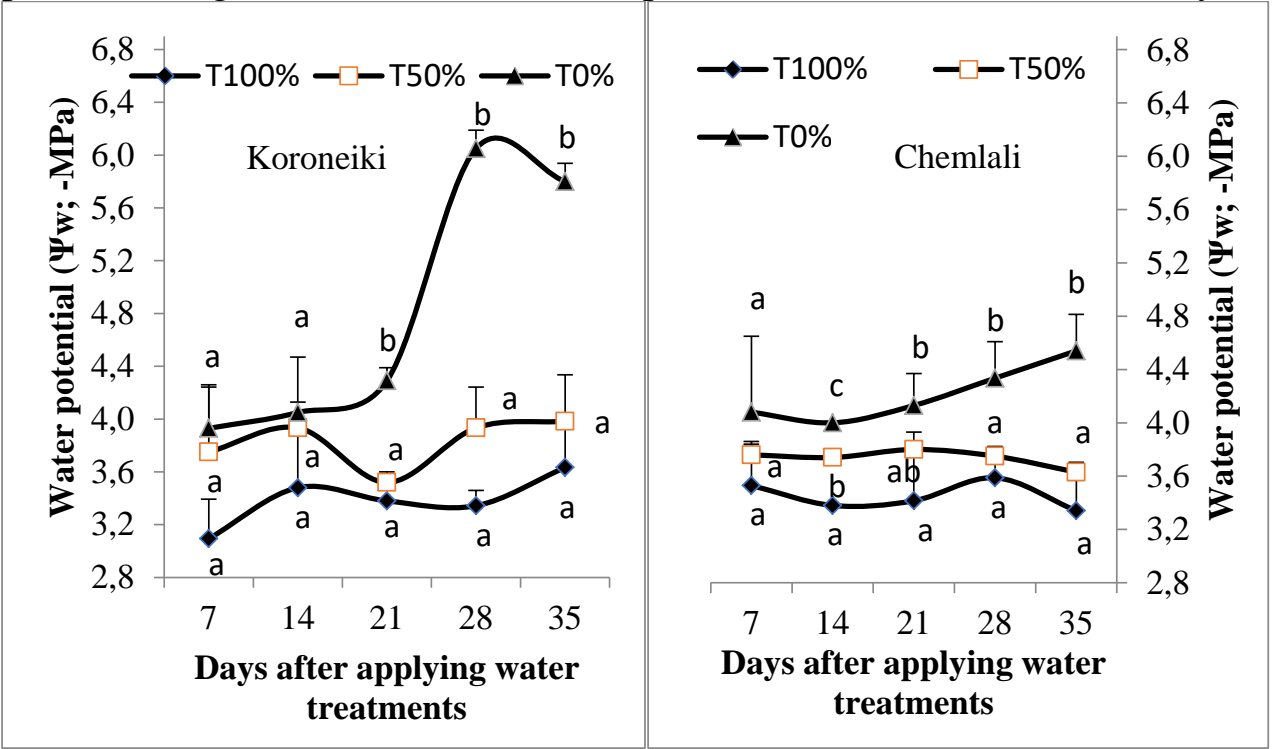

Figure 1. Leaf water potential ( $\Psi \mathrm{w},-\mathrm{MPa})$ of olive tree (Olea europaea L. cv Koroneiki and Chemlali) under three water treatments during 35 days after applying water treatments. Each value represents the mean \pm standard deviation of three measures. The average of each value followed by the same letter do not differ statistically between treatment - SNK P $<5 \%$. 


\section{Effect of three water treatments on leaf osmotic adjustment}

Figure 2 indicates that, for Koroneiki plants, T50\% plants show a very low osmotic adjustment $(0.16 \mathrm{MPa})$ that decreases throughout the experiment. However, for Koroneiki T0\% plants, the osmotic adjustment did not exceed $0.5 \mathrm{MPa}$ after 21 days of applying water treatments. Then, it increases strongly by $85 \%$ and reaches $2.46 \mathrm{MPa}$, after 28 days of applying water treatments.

At the end of the experiment, the osmotic adjustment of $\mathrm{T} 50 \%$ and T0\% plants reaches 0.08 and $2.02 \mathrm{MPa}$ respectively.

Chemlali plants show a progressive increase of their osmotic adjustment throughout the experiment, for both water treatments (50\% AWC and $0 \%$ AWC). At the last day of the experiment, the osmotic adjustment of Chemlali T50\% and T0\% plants reaches 1.25 and $1.7 \mathrm{MPa}$, respectively.

Giron et al. (2015) showed that the physiological response of the trees (osmotic adjustment and trunk dehydration) compensated the decrease in water potential.

The ability of olive trees to reach such (extremely) negative $\Psi_{\mathrm{w}}$ values is partially due to osmotic adjustment. Osmotic adjustment allows plants to tolerate temporary or prolonged periods of water shortage and is one of the crucial processes involved in plant adaptation to drought (Chaves et al., 2003). According to Dichio et al. (2003), osmotic adjustment is one of the early mechanisms of trees in respond to water stress (i.e. in olive trees).

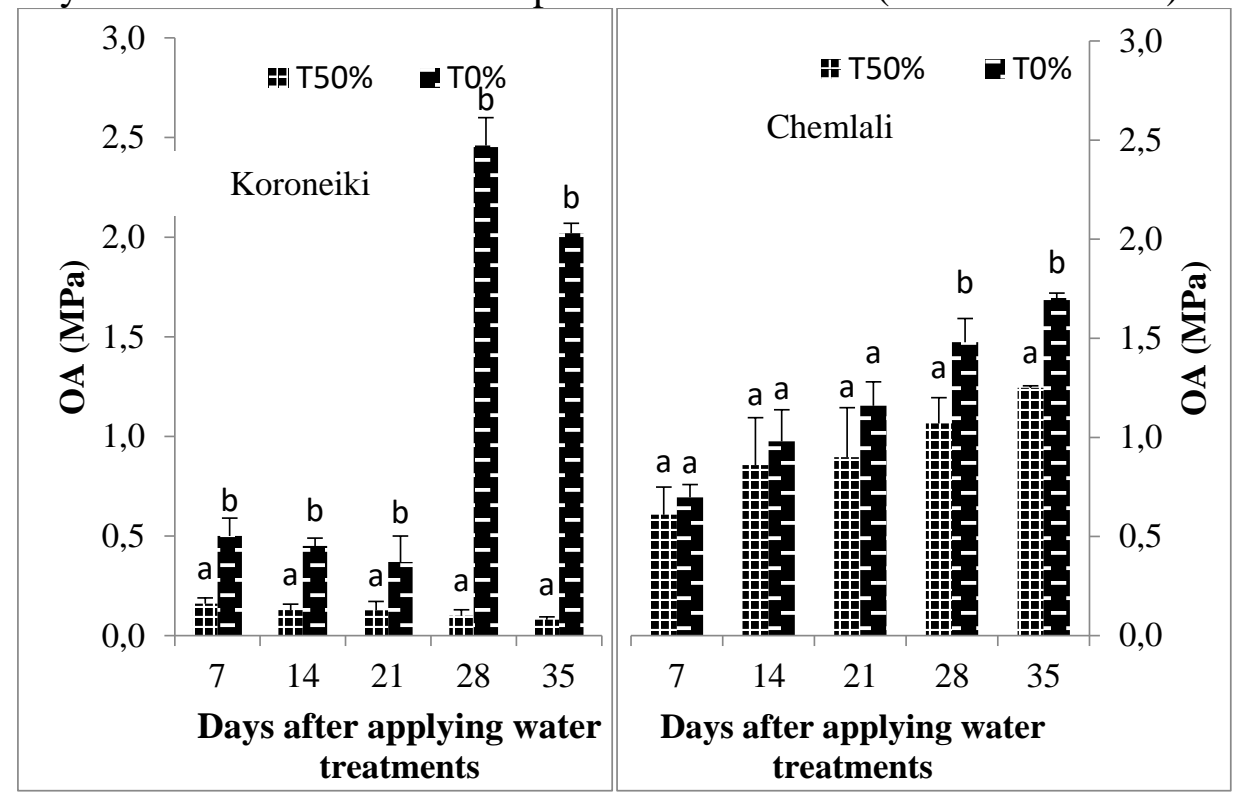

Figure 2. Leaf osmotic adjustment (OA, MPa) of olive tree (Olea europaea L. cv Koroneiki and Chemlali) under two water treatments during 35 days after applying water treatments. Each value represents the mean \pm standard deviation of three measures. The average of each value followed by the same letter do not differ statistically between treatment - SNK P $<5 \%$. 


\section{Effect of three water treatments on gas exchange Effect of three water treatments on stomatal conductance}

Figure 3 shows the effect of three water treatments on the leaf stomatal conductance (gs) of Koroneiki and Chemlali cultivars. For the both cultivars, at T100\%, plants show the highest stomatal conductance, however T0\% ones show the lowest value. We noted a significant difference between Koroneiki $\mathrm{T} 100 \%$ and $\mathrm{T} 50 \%$ plants after 14 days of the start of the experiment. The T0\% plants of the same cultivar show a low stomatal conductance that ranges between 0.026 and $0.011 \mathrm{~mol} \mathrm{H}_{2} \mathrm{O} \mathrm{m}^{-2} \mathrm{~s}^{-1}$.

Chemlali plants demonstrated a significant difference between the three water treatments after 7 days of applying water treatments. This difference was maintained throughout the experimental period. At the $35^{\text {th }}$ day, no significant difference was observed between cultivars for the three water doses.

As a mechanism of adaptation to water restriction, the stomatal conductance limits the photosynthesis (A) rate by closing the stomata, so the photosynthesis decreases. The stomatal conductance of Koroneiki plants at $\mathrm{T} 100 \%$ ranges between 0.17 and $0.255 \mathrm{~mol} \mathrm{H}_{2} \mathrm{O} \mathrm{m}^{-2} \mathrm{~s}^{-1}$. However, Chemlali plants for the same treatment, stomatal conductance ranges between 0.16 and $0.297 \mathrm{~mol} \mathrm{H}_{2} \mathrm{O} \mathrm{m}^{-2} \mathrm{~s}^{-1}$. For Koroneiki plants receiving 50\% AWC, the stomatal conductance ranges between 0.123 and $0.227 \mathrm{~mol} \mathrm{H}_{2} \mathrm{O} \mathrm{m}^{-2} \mathrm{~s}^{-1}$. Whereas, Chemlali plants stomatal conductance ranges between 0.087 and $0.217 \mathrm{~mol} \mathrm{H}_{2} \mathrm{O} \mathrm{m}^{-2} \mathrm{~s}^{-1}$.

Stomatal closure, to maintain the leaf's water balance, decreases A and thus biomass production of plants (Lawlor, 2002; Farineau and MorotGaudry, 2006). A controversy exists already for several years as to whether stomatal closure or biochemical impairment limits most photosynthesis under drought stress. Cornic (2000) concluded that the stomatal part is the primary and, therefore, probably the most important limiting factor, but the debate is up to today still ongoing. Fernandez (2014) indicated that the role of stomata is to regulate the entry of sufficient $\mathrm{CO}_{2}$ for optimal photosynthesis while conserving water inside the plant. As in many other plants well adapted to dry areas, stomatal closure in olive limits transpiration.

In potted olive trees, Angelopoulos et al. (1996) and Boussadia et al. (2008) determined that stomatal conductance (gs) was limiting photosynthesis (A) in trees subjected to mild and moderate water stress. 


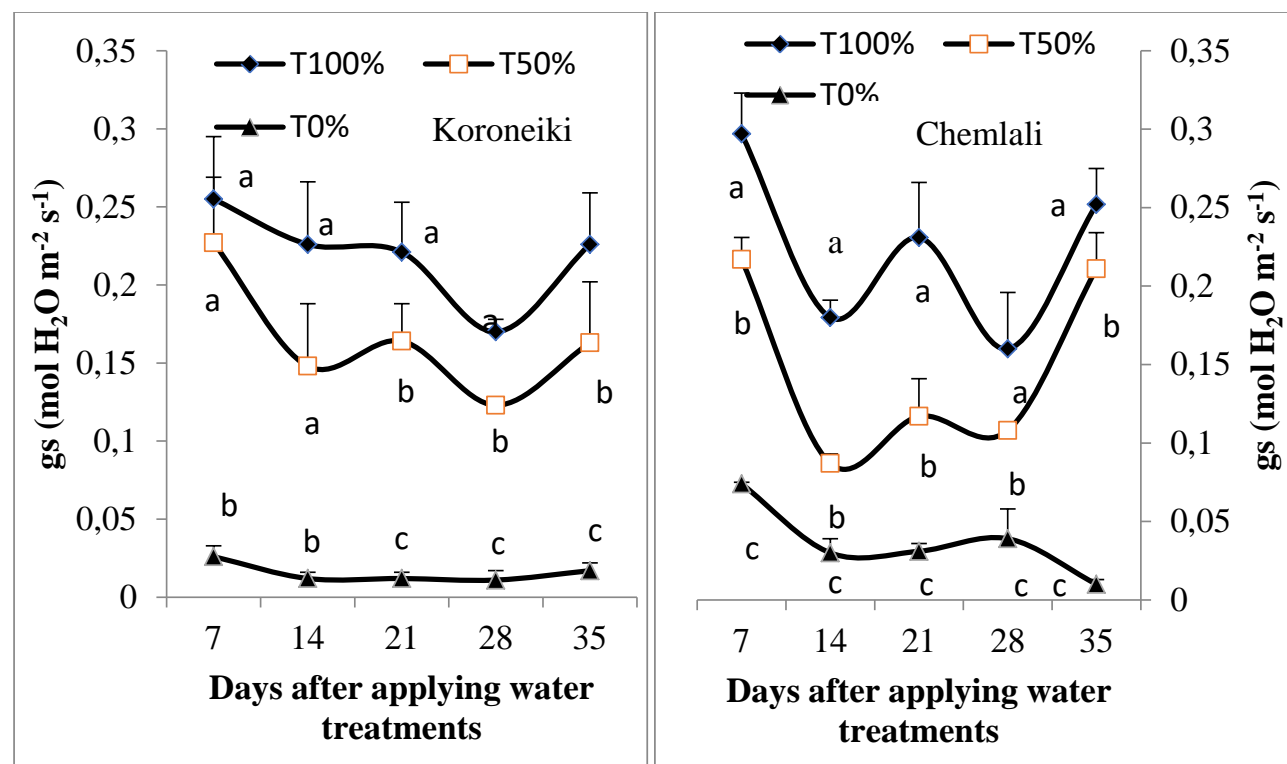

Figure 3. Leaf stomatal conductance (gs, $\mathrm{mol} \mathrm{H}_{2} \mathrm{O} \mathrm{m}^{-2} \mathrm{~s}^{-1}$ ) of olive tree (Olea europaea L. cv Koroneiki and Chemlali) under three water treatments during 35 days after applying water treatments. Each value represents the mean \pm standard deviation of three measures. The average of each value followed by the same letter do not differ statistically between treatments- SNK P $<5 \%$.

\section{Effect of three water treatments on photosynthesis}

The effect of three water treatments on the leaf photosynthesis (A) of Koroneiki and Chemlali olive plants was given in figure 4. For both cultivars, plants at $\mathrm{T} 100 \%$ show the highest photosynthesis rate whereas T0\% plants show the lowest one. For Koroneiki plants, a significant difference was noticed after 14 days of applying water treatments between plants treated at $\mathrm{T} 100 \%$ and $\mathrm{T} 50 \%$. Koroneiki $\mathrm{T} 0 \%$ plants show a low photosynthetic rate that decreases from $4.08 \mu \mathrm{mol} \mathrm{CO}_{2} \mathrm{~m}^{-2} \mathrm{~s}^{-1}$, to $0.2 \mu \mathrm{mol}$ $\mathrm{CO}_{2} \mathrm{~m}^{-2} \mathrm{~s}^{-1}$, at the end of the experimental period.

For Chemlali plants, a significant difference was noticed between T0\% and $\mathrm{T} 100 \%$ plants during the whole experiment. However, no significant difference was recorded at the end of the experimental period between T100\% and T50\% plants. As for Koroneiki T0\% plants, the photosynthesis rate of Chemlali plants decreases from $8.46 \mu \mathrm{mol} \mathrm{CO}_{2} \mathrm{~m}^{-2} \mathrm{~s}^{-1}$, to $1.29 \mu \mathrm{mol}$ $\mathrm{CO}_{2} \mathrm{~m}^{-2} \mathrm{~s}^{-1}, 35$ days after applying water treatments. The photosynthesis rate decreases strongly for Koroneiki T0\% plants than Chemlali ones. So we can deduce that Chemlali plants seem to present more plasticity to water restriction than Koroneiki plants.

Despite the decreasing trend in A due to turgidity loss which compromises cell metabolism and, in particular, the photosynthetic system, the results confirm the capacity of olive tissues to continue with 
photosynthesis during prolonged water restriction and to lose tissue water through transpiration ensuring some photosynthesis in case of missing or insufficient irrigation. Similar results were also reported by Dichio et al., (2005) for Coratina olive trees. Petridis et al. (2012) determined that photosynthetic rate was reduced mainly due to stomatal closure. Cultivars having high rates of carbon uptake, when conditions are favorable, decrease rapidly upon installing and during the water stress treatment. These cultivars can be categorized as opportunistic. Maximum reduction in A was observed after 35 days of water stress: values reduced to $80 \%$ and $56 \%$ compared to control values for Koroneiki and Chemlali, respectively. Similar results have been reported by Braham (1997) and Boussadia et al. (2008) for the same cultivars. Chartzoulakis et al. (1999) noted that the photosynthetic activity in two olive tree cultivars Koroneiki and Mastoid declined during the development of progressive water restriction. Similar effects have been reported by other researchers (e.g. Giorio et al., 1999) noting that the photosynthesis rates of olive trees decreased by $50 \%$ when water supply changed from 66\% to 33\% ETP (evapotranspiration).

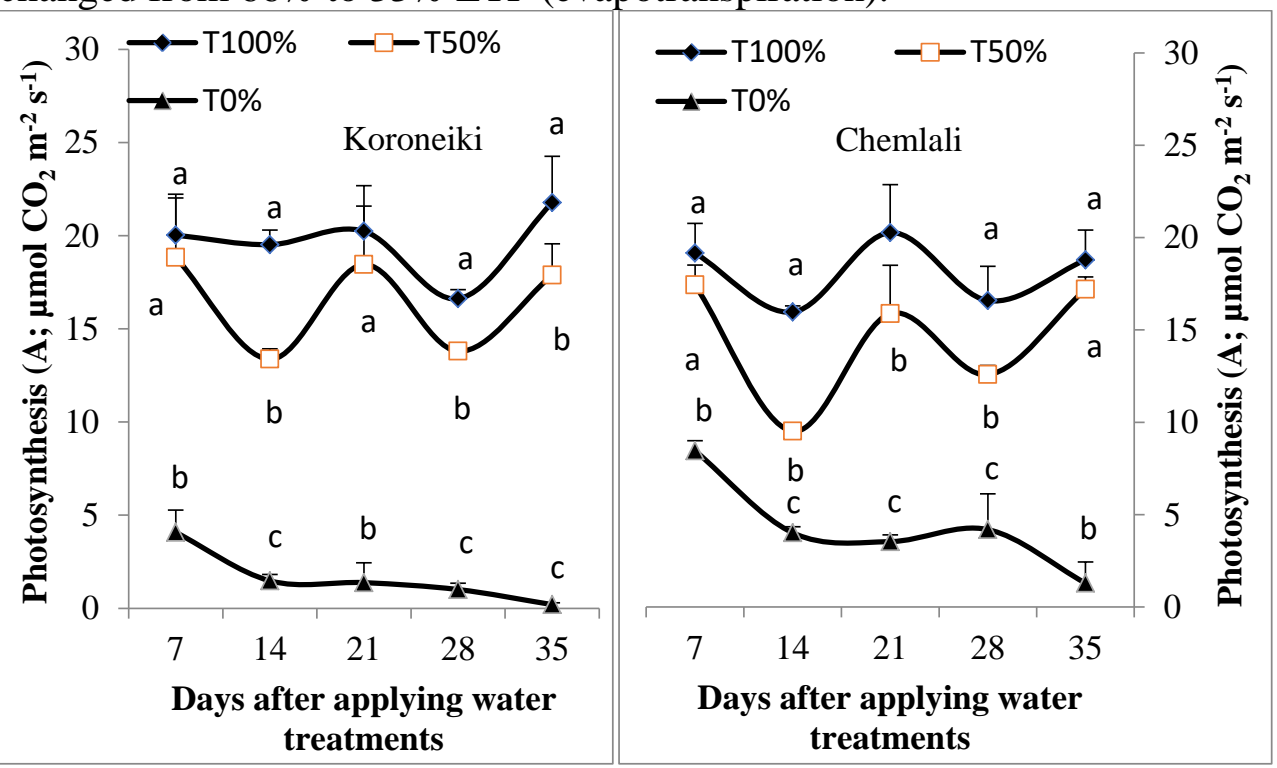

Figure 4. Leaf photosynthesis (A, $\mu \mathrm{mol} \mathrm{CO}_{2} \mathrm{~m}^{-2} \mathrm{~s}^{-1}$ ) of olive tree (Olea europaea $\mathrm{L}$. cv Koroneiki and Chemlali) under three water treatments during 35 days after applying water treatments. Each value represents the mean \pm standard deviation of three measures. The average of each value followed by the same letter do not differ statistically between treatments - SNK P $<5 \%$.

\section{Effect on intrinsic water use efficiency}

The intrinsic WUE of Koroneiki, expressed as the ratio A/gs, shows no significant difference between $\mathrm{T} 100 \%$ and $\mathrm{T} 50 \%$ plants throughout the experiment (Figure 5). However, for Chemlali plants, T50\% presents a better 
intrinsic WUE than T100\% plants. A significant difference is maintained between $\mathrm{T} 100 \%$ and $\mathrm{T} 50 \%$ during the experiment period. Koroneiki WUE ranged between 83 to $98 \mu \mathrm{mol} \mathrm{CO} \mathrm{CO}^{-2} \mathrm{~s}^{-1}$ compared to Chemlali WUE that ranged between 80 and $135 \mu \mathrm{mol} \mathrm{CO} \mathrm{m}^{-2} \mathrm{~s}^{-1}$ for $\mathrm{T} 50 \%$ treatment.

This result indicates that Chemlali plants valorizes better low quantities of water (T50\%) rather than high quantities (T100\% plants). A significant difference between Koroneiki and Chemlali plants for the two water treatments was shown, 35 days after applying water treatments.

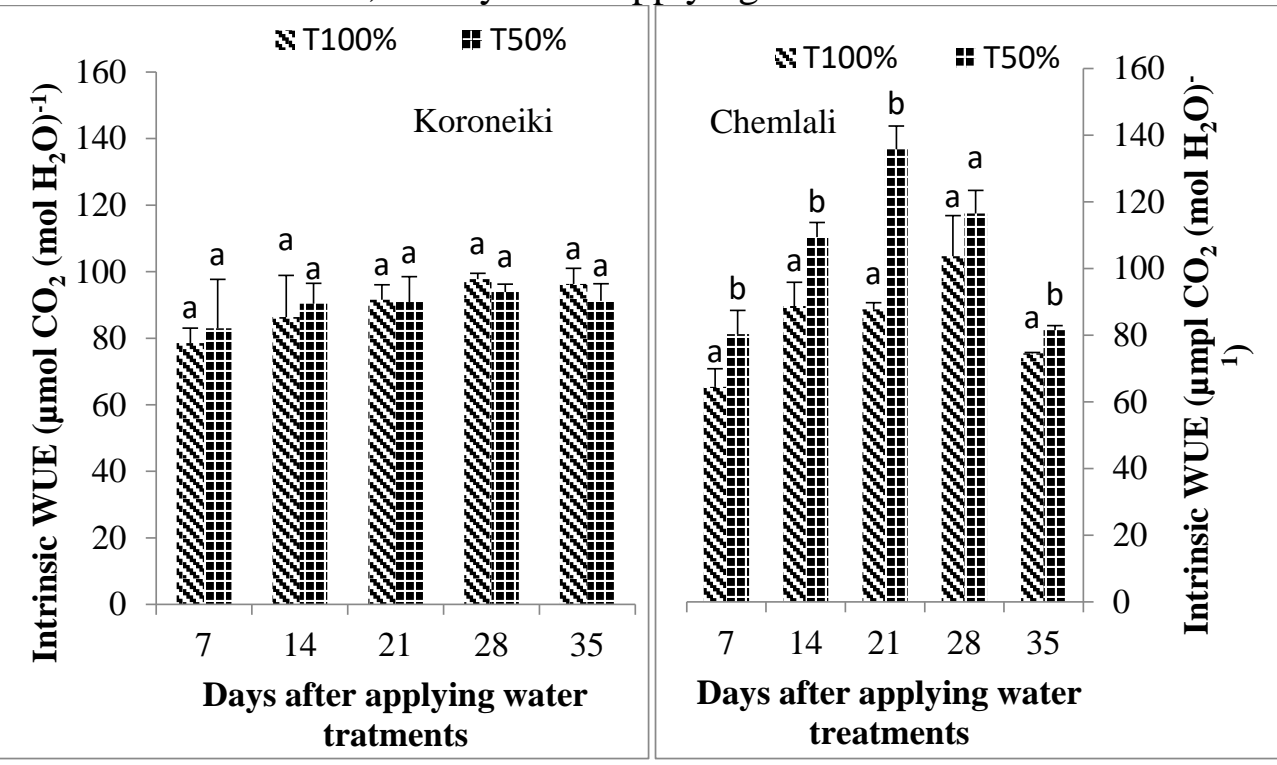

Figure 5. Intrinsic water use efficiency $\left(\mu \mathrm{mol} \mathrm{CO} \mathrm{CO}_{2}\left(\mathrm{~mol} \mathrm{H}_{2} \mathrm{O}\right)^{-1}\right)$ of olive tree $($ Olea europaea L. cv Koroneiki and Chemlali) under two water treatments during 35 days after applying water treatments. Each value represents the mean \pm standard deviation of three measures. The average of each value followed by the same letter do not differ statistically between treatments - SNK P $<5 \%$.

\section{Effect of three water treatments on plant dry matter accumulation}

For both cultivars, root dry weight (DW) was significantly affected by the three water treatments. Koroneiki plants at T100\% show the highest root DW. However, for Chemlali plants, the highest one was shown at $\mathrm{T} 50 \%$ (Table 1).

At $\mathrm{T} 100 \%$, leaves DW of Koroneiki cultivar show a significant difference with the other treatments (T50\% and T0\%). For Chemlali at T50\%, plants show the highest leaves DW but no significant difference is found, between the three water treatments.

The highest Koroneiki stem DW was obtained in plants treated at $\mathrm{T} 100 \%$ and $\mathrm{T} 50 \%$ compared to $\mathrm{T} 0 \%$. Whereas, for Chemlali plants, no significant difference was found between the three water treatments. 
The root/shoot ratio of Chemlali plants at T50\% treatment was the highest (1.08) comparatively with the other two treatments. This result shows that Chemlali plants valorize low quantities of water (T50\%) rather than high quantities (T100\%). However, for Koroneiki at T100\% treatment plants show the best root/shoot ratio compared to $\mathrm{T} 50 \%$ and $\mathrm{T} 0 \%$. This result seems to indicate that Koroneiki plants behave better when it is irrigated at $100 \%$ AWC.

To reach this objective, plants subjected to water deficiency, close their stomata, reduce water losses and limit transpiration and carbon assimilation (Giorio et al., 1999). Such a reduction of photoassimilates availability causes, at whole plant level, a change in the pattern of dry matter distribution: shoot growth will be inhibited while a higher quantity of assimilates will be transported and accumulated in the root system determining a higher root/shoot ratio in water stressed plants (Xiloyannis et al., 1999). Di Vaio et al. (2013) mentioned that, under different water regimes applied on young pot-grown olive trees, the dry matter was affected by the water regime and cultivar. Indeed, the cv Leccino, full irrigated, displayed a greater accumulation of total dry matter and fruit dry matter, while these two parameters were greatly reduced under the other water regimes (T50 and T25). By contrast, the cv Racioppella always showed a lower accumulation of dry matter and a more balanced canopy/root ratio.

Nevertheless, water stress is not the only parameter that affects dry matter distribution in the plant; in particular, many agronomic and genetic factors, such as rootstock, cultivar, training system, pruning and planting density have been shown to influence growth and to modify the distribution of biomass between roots and canopy (canopy/roots ratio) and between the different plant organs (Caruso et al., 1997, 2001, 2008; Zucconi, 1992; Xiloyannis et al., 2007; Di Vaio et al., 2012; Weibel and Reighard, 2012; Yano et al., 2002).

Several cultivars respond differently to drought, showing differences in terms of adaptation, dry matter distribution, production and gas exchange responses to water shortage (Chartzoulakis et al.,1999; Bacelar et al., 2004, 2007; Tognetti et al., 2002). 
Table 1. Root, leaves and stem dry weight (g/plant) and root/shoot ratio of olive tree (Olea europaea L. cv Koroneiki and Chemlali) under three water treatments, 35 days after applying water treatments. Each value represents the mean \pm standard deviation of three measures. The average of each value followed by the same letter do not differ statistically SNK $\mathrm{P}<5 \%$. The first letter is for the statistical analysis within the cultivar and the second is for the statistical analysis within the water treatment.

\begin{tabular}{|c|c|c|c|c|c|}
\hline $\begin{array}{l}\text { Cultivar } \\
\text { treatmen }\end{array}$ & -Water & $\begin{array}{l}\text { Root Dry } \\
\text { (g/plant) }\end{array}$ & $\begin{array}{l}\text { Leaves Dry } \\
\text { Weight (g/plant) }\end{array}$ & $\begin{array}{l}\text { Stem Dry Weight } \\
\text { (g/plant) }\end{array}$ & Root/shoot ratio \\
\hline \multirow{3}{*}{ 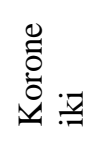 } & $\mathrm{T} 100 \%$ & $45.96 \pm 2.32^{\mathrm{a}, \mathrm{a}}$ & $30.40 \pm 4.74^{\mathrm{a}, \mathrm{a}}$ & $32.76 \pm 2.62^{\mathrm{a}, \mathrm{a}}$ & $0.70 \pm 0.04^{\mathrm{a}, \mathrm{a}}$ \\
\hline & $\mathrm{T} 50 \%$ & $29.50 \pm 2.48^{\mathrm{b}, \mathrm{a}}$ & $18.96 \pm 3.28^{\mathrm{b}, \mathrm{a}}$ & $29.26 \pm 2.35^{\mathrm{a}, \mathrm{a}}$ & $0.61 \pm 0.02^{\mathrm{b}, \mathrm{a}}$ \\
\hline & T0\% & $16.51 \pm 0.62^{\mathrm{c}, \mathrm{a}}$ & $12.79 \pm 2.51^{\mathrm{b}, \mathrm{a}}$ & $17.73 \pm 3.43^{\mathrm{b}, \mathrm{a}}$ & $0.55 \pm 0.10^{\mathrm{b}, \mathrm{a}}$ \\
\hline \multirow{3}{*}{ 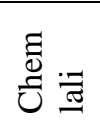 } & $\mathrm{T} 100 \%$ & $24.97 \pm 3.97^{\mathrm{ab}, \mathrm{b}}$ & $16.85 \pm 4.31^{\mathrm{a}, \mathrm{b}}$ & $18.51 \pm 4.68^{\mathrm{a}, \mathrm{b}}$ & $0.70 \pm 0.07^{\mathrm{a}, \mathrm{a}}$ \\
\hline & T50\% & $33.80 \pm 5.37^{\mathrm{b}, \mathrm{a}}$ & $17.46 \pm 7.51^{\mathrm{a}, \mathrm{a}}$ & $16.07 \pm 5.62^{\mathrm{a}, \mathrm{b}}$ & $1.08 \pm 0.29^{\mathrm{a}, \mathrm{b}}$ \\
\hline & T0\% & $20.41 \pm 4.91^{\mathrm{a}, \mathrm{a}}$ & $11.10 \pm 1.52^{\mathrm{a}, \mathrm{a}}$ & $14.64 \pm 1.10^{\mathrm{a}, \mathrm{a}}$ & $0.79 \pm 0.13^{\mathrm{a}, \mathrm{a}}$ \\
\hline
\end{tabular}

\section{Conclusion}

Our results showed that, as water stress increases (T0\%), the cultivar Chemlali belong more resistant to water restriction than Koroneiki by maintaining longer a high (less negative) midday leaf water potential. Measurements of osmotic adjustment showed that olive trees use this mechanism to create very negative leaf water potentials in order to be able to extract water from a dry root environment. Chemlali plants showed a progressive increase of their osmotic adjustment throughout the experiment, for both water treatments (50\% AWC and 0\% AWC). This Chemlali cultivar stress management strategy was confirmed by measurements of stomatal conductance showing a significant difference between the three water treatments from the first week after applying water treatments. However, for Koroneiki cultivar, the stress management strategy was not as remarkable as Chemlali cultivar. As a mechanism of adaptation to water restriction, the stomatal conductance limited the photosynthesis rate by closing the stomata, so the photosynthesis decreases and thus the biomass production of plants. Such a reduction of photoassimilates availability causes, a higher root/shoot ratio in water stressed plants (1.08 for Chemlali T50\% plants). In consequence, Chemlali T50\% plants showed the highest intrinsic water use efficiency compared to Koroneiki plants. In conclusion, the assessment of the behavior of two young olive tree cultivars Koroneiki and Chemlali under water restriction conditions based on water status, eco-physiological and dry matter accumulation parameters showed that olive tree (Olea europaea L.) local cultivar Chemlali irrigated at 50\% AWC, compared to Koroneiki cultivar, is the most suitable cultivar to tolerate water restriction conditions. 


\section{Acknowledgments}

The authors acknowledge the Olive tree Institute (Unit of Sousse) technical staff for the help and support that they gave us during the whole realization period of this research.

\section{References}

1. Angelopoulos, K., Dichio, B., \& Xiloyannis, C. (1996). Inhibition of photosynthesis in olive trees (Olea europaea L.) during water stress and rewatering. Journal of Experimental Botany, 47(8), 1093-1100.

2. Bacelar, E. A., Correia, C. M., Moutinho-Pereira, J. M., Gonçalves, B. C., Lopes, J. I., \& Torres-Pereira, J. M. (2004). Sclerophylly and leaf anatomical traits of five field-grown olive cultivars growing under drought conditions. Tree physiology, 24(2), 233-239.

3. Bacelar, E. A., Moutinho-Pereira, J. M., Gonçalves, B. C., Ferreira, H. F., \& Correia, C. M. (2007). Changes in growth, gas exchange, xylem hydraulic properties and water use efficiency of three olive cultivars under contrasting water availability regimes. Environmental and Experimental Botany, 60(2), 183-192.

4. Boussadia, O., Mariem, F. B., Mechri, B., Boussetta, W., Braham, M., \& El Hadj, S. B. (2008). Response to drought of two olive tree cultivars (cv Koroneki and Meski). Scientia horticulturae, 116(4), 388-393.

5. Braham, M. (1997). Activité écophysiologique, état nutritif et croissance de l'olivier (Olea europaea L.) soumis à une contrainte hydrique, thèse d'État, faculté des sciences agronomiques de Gand, Belgique. 160 p.

6. Caruso, T., Inglese, P., Sidari, M., \& Sottile, F. (1997). Rootstock influences seasonal drymatter and carbohydrate content and partitioning in above-ground componentsof Flordaprince peach trees. J. Am. Soc. Hortic. Sci. 122 (5), 673-679.

7. Caruso, T., Barone, E., \& Di Vaio, C. (2001). Factors affecting tree crop efficiency in youngpeach trees: rootstock vigour and training system. Acta Hortic. 557, 193-197.

8. Caruso, T., Motisi, A., Pernice, F., \& Di Vaio, C. (2008). Peach planting systems in southernItaly: ecophysiological aspects and technical developments. Acta Hortic. 772,423-430.

9. Chartzoulakis, K., Patakas, A., \& Bosabalidis, A. M. (1999). Changes in water relations, photosynthesis and leaf anatomy induced by intermittent drought in two olive cultivars. Environmental and experimental botany, 42(2), 113-120. 
10. Chaves, M. M., Maroco, J. P., \& Pereira, J. S. (2003). Understanding plant responses to drought-from genes to the whole plant. Functional plant biology, 30(3), 239-264.

11. Chazen, O., Hartung, W., \& Neumann, P. M. (1995). The different effects of PEG 6000 and $\mathrm{NaCI}$ on leaf development are associated with differential inhibition of root water transport. Plant, Cell \& Environment, 18(7), 727-735.

12. Cornic, G. (2000). Drought stress inhibits photosynthesis by decreasing stomatal aperture not by affecting ATP synthesis. Trends in Plant Science 5, 187-188.

13. Dichio, B., Xiloyannis, C., Angelopoulos, K., Nuzzo, V., Bufo, S. A., \& Celano, G. (2003). Drought-induced variations of water relations parameters in Olea europaea. Plant and Soil, 257(2), 381-389.

14. Dichio B, Xiloyannis C, Sofo A, \& Montanaro G., 2005. Osmotic regulation in leaves and root of olive trees during a water deficit and rewatering. Tree physiology 26. pages 179-185.

15. Di Vaio, C., Marra, F.P., Scaglione, G., La Mantia, M. \& Caruso, T. (2012). The effect of different vigour olive clones on growth, dry matter partitioning and gas exchange under water deficit. Scientia Horticulturae 134, 72-78.

16. Di Vaio, C., Marallo, N., Marino, G., \& Caruso, T. (2013). Effect of water stress on dry matter accumulation and partitioning in potgrown olive trees (cv Leccino and Racioppella).Scientia Horticulturae, 164, 155-159.

17. Farineau, J., \& Morot-Gaudry, J. F. (2006). La photosynthèse: processus physiques, moléculaires et physiologiques. Editions Quae.

18. Fernández, J. E. (2014). Understanding olive adaptation to abiotic stresses as a tool to increase crop performance. Environmental and Experimental Botany, 103, 158-179.

19. Giorio, P., Sorrentino, G., \& d’Andria, R. (1999). Stomatal behaviour, leaf water status and photosynthetic response in field grown olive trees under water deficit. Environmental and Experimental Botany, 42(2), 95-104.

20. Girón, I. F., Corell, M., Galindo, A., Torrecillas, E., Morales, D., Dell'Amico, J., \& Moriana, A. (2015). Changes in the physiological response between leaves and fruits during a moderate water stress in table olive trees. Agricultural Water Management, 148, 280-286.

21. Lawlor, D. W. (2002). Limitation to Photosynthesis in Water-stressed Leaves: Stomata vs. Metabolism and the Role of ATP. Annals of botany, 89(7), 871-885.

22. Marino, G., Pallozzi, E., Cocozza, C., Tognetti, R., Giovannelli, A., Cantini, C., \& Centritto, M. (2014). Assessing gas exchange, sap 
flow and water relations using tree canopy spectral reflectance indices in irrigated and rainfed Olea europaea L. Environmental and Experimental Botany, 99, 43-52.

23. Mediavilla, S., Santiago, H. and Escudero, A. (2002). Stomatal and mesophyll limitation to photosynthesis in one deciduous Mediterranean ouk species. Photosynthetica 40, 553-587.

24. Petridis, A., Therios, I., Samouris, G., Koundouras, S., \& Giannakoula, A. (2012). Effect of water deficit on leaf phenolic composition, gas exchange, oxidative damage and antioxidant activity of four Greek olive (Olea europaea L.) cultivars. Plant physiology and biochemistry, 60, 1-11.

25. Tognetti, R., Costagli, G., Minnocci, A., \& Gucci, R. (2002). Stomatal behaviour and water use efficiency in two cultivars of Olea europaea L. Agr. Med, 132, 90-97.

26. Weibel, A.M. and Reighard, G.L. (2012). Dwarfing peach rootstocks generate scion water stress. Acta Hortic. 962 (October), 633-640.

27. Xiloyannis, C., Dichio, B., Nuzzo, V., Celano, G. (1999). Defence strategies of olive against water stress. Acta Hort. 474, 423-426.

28. Xiloyannis, C., Sofo, A., Celano, G., \& Nuzzo, V. (2007). Absorption of atmospheric $\mathrm{CO} 2$ in peach trees and partitioning in the different plant organs. Acta Hortic. 732,519-524.

29. Yano, T., Inoue, H., Shimizu, Y., Shinkai, S. \& Ochi, M. (2002). Effects of Prunus tomentosa and P. persica rootstocks on yield, fruit quality, dry matter partitioning and trunkcross-sectional areas of six peach cultivars. J. Jpn. Soc. Hortic. Sci. 71 (November(6)), 730-737.

30. Zucconi, F. (1992). Controllo dello sviluppo nelle piante arboree: introduzione alla fisiologia della potatura. Frutticoltura 12, 7-12. 